\title{
Art Management
}

\section{as Administrative System \\ of Broadcast of Art Values}

\author{
Sergey V. Kostylev* \\ Siberian Federal University \\ 79 Svobodny, Krasnoyarsk, 660041, Russia
}

Received 07.10.2014, received in revised form 26.12.2014, accepted 08.04.2015

The article considers the peculiarities of functioning and development of art management as the most important mechanism for regulation and support of management system in the sphere of culture, art and education, aimed at solution of tasks on preservation and development of artistic creativity; augmentation of aesthetic, educational, cultural, educational, spiritual, moral and patriotic values; creation, presentation and promotion of highly artistic products of art. It examines the types and functions of art management responsible for development and implementation of the educational activity strategy; execution of systematic activity on preparation, retraining and development of the common cultural and professional level of employees of culture and art institutions.

Keywords: art management, varieties and features of art management, art marketing.

DOI: 10.17516/1997-1370-2015-8-8-1611-1624.

Research area: culture studies, philosophy.

Research of role and significance of art management becomes especially urgent due to the gradual inclusion of culture and art into market relations, thereby requiring scientific review and theoretical summary of management mechanisms on the level of positioning and promotion of sociocultural educational services.

In this regard, the main task of art management as a type of management activity is the increase of theoretical significance and practical applicability of methods and technologies for solving numerous problems of development and functioning of sociocultural and artistic educational institutions.
Art management is studied as a means for efficient management and regulation of cultural sphere personnel training system under the conditions of deficit of resources, being the main technological tool for forming efficient environment for creation and promotion of artistic values within the sociocultural educational space.

Therefore, the purpose of the present research is to reveal the specificity and significance of modern art management as a complex system of principles, functions, methods and technologies within the structure of sociocultural management targeted at the formation, functioning and

(C) Siberian Federal University. All rights reserved

* Corresponding author E-mail address: profikost@mail.ru 
development of the educational space for the production, reproduction and distribution of the artistic ideals, examples, values and practices.

The used research methods are: analysis, synthesis, observation, generalization, content analysis of documents, concretization, systematization and classification.

Modern art management should be regarded in at least two aspects: as a major component of sociocultural management and as a relatively independent system including purposes and tasks, rules and principles, functions and tools, methods and technologies for its implementation.

The category of art management includes a series of parameters revealing the peculiarities of the phenomenon, and at the same time creating the whole idea of its essentials, specificity, functions and mechanisms. Such parameters and areas include:

- analysis of the internal and the external media: monitoring of the conditions of the institution's work in order to reveal, assess and regulate the risks threatening the associated parties, their changing interests, needs and expectations;

- mission and vision: expression of philosophy and meaning of existence, promotion and positioning of the underlying principles of the sociocultural purpose of an institution of culture and art;

- target setting and planning: development and design of sociocultural and artistic measures adequately reflecting the needs of the society for the protection of essential rights and interests of the new generation in the fields of education, culture, art, and leisure; formation of the conditions necessary for their development;

- management subject: art managers delegated to exercise their authorities in the field of management decision-making in certain fields of the institution's activity;

- management object: totality of interconnected structural subdivisions of different purposes (branches, departments, sectors etc.) exposed to management influence of the management subject for the efficient achievement of the set targets;

- management activity system: totality of mechanisms ensuring the fulfillment of the targets, tasks and functions of management, preparation and implementation of management decisions in the field of culture and art;

- content and organizational forms: complex of priorities and features required for the creation of conditions and opportunities for successful socialization, enculturation and efficient self-fulfillment of the educational service consumers for the development of their potential for the benefit of Russia and, therefore, for the socioeconomic, educational and cultural development of the country;

- personnel management and personnel policy: totality of principles, technologies, methods and forms determining the underlying strategy and tactics of working with personnel for the sake of preservation, strengthening and development of the personnel potential;

- information and communication complex: a system for distributing the data subject to storage, processing and transmission, consisting of a number of interconnected components: sender, distribution channels, coding and decoding processes, content, message, efficiency, control, addressee;

- strategizing: a process for development and fulfillment of prospective planning 
as a complex of measures for forecasting of the expected development results and avoiding deviations of the forecasted consequences of the selected target based on the analysis of the external media factors;

- principles: underlying and directing rules for activity for the efficiency of functioning and development of the institution;

- functions: totality of actions based on separation and integration of management activities and characterized with a certain grade of optimality, complexity, wholeness and stability of impact on the subject and the object of management;

- ethics and corporate culture: a totality of values, signs, symbols, regulations, ideas, that form the style of thinking and behavior of the institution staff both consciously and subconsciously;

- infrastructure and resources: conditions and opportunities required for the achievement of short-term and long-term management objectives;

- methods and technologies of organization and fulfillment: means and mechanisms of management activity, setting of targets, fulfillment of tasks and execution of solutions for different sociocultural educational problems; tools for development, approbation and implementation of creative, recreating, animating and educational projects and programs into the artistic practice;

- art marketing: a specific function of art management, a totality of actions targeted at the satisfaction of the consumers' needs by means of product (commodity or service) and a number of factors connected with creation, supply and consumption of the sociocultural product;
- efficiency criteria: markers and indicators for conducting assessment, evaluation or classification of effectiveness, efficiency and efficacy of art management.

All these main areas of art management are tightly interconnected, manifesting themselves as components of a single process, sharing each other's advantages and peculiarities.

Based on the analysis of a series of governmental documents issued within the recent years and defining the process of management in the field of art and artistic practice, we may come up with the following generalized idea of modern art management purposes and outline its main features and priorities:

- ensuring functioning and development of art in the society, design and conduct of artistic, creative actions and events (festivals, concerts, performances, plays, exhibitions, competitions, workshops etc.)

- ensuring creative-productive and advertising-marketing types of activities with the purpose of efficient fulfillment of the target sociocultural projects and programs;

- enhancement of the impact made by works of art on the social and cultural media of the society;

- popularization of objects of art and culture classified as artistic and historical heritage;

- development of artistic and aesthetic values, ideals and views of personality through professional, social and outreach activities;

- fulfillment of innovation potential of the youth for the social development of the youth itself;

- creation of conditions for sufficient personal and professional formation 
Table 1. Types of art management

\begin{tabular}{|c|c|}
\hline $\begin{array}{l}\text { Types of art } \\
\text { management }\end{array}$ & Explanation \\
\hline \multicolumn{2}{|r|}{ Performing and scenic art management } \\
\hline Music management & $\begin{array}{l}\text { Organization, planning, and management of processes for creation and distribution } \\
\text { of music products in the fields of culture, sound recording industry, television and } \\
\text { radio broadcasting, club promotion, and production. Feasibility studies, technical and } \\
\text { economic calculation of competitiveness and efficiency of marketing structures in } \\
\text { show business }\end{array}$ \\
\hline Theatre management & $\begin{array}{l}\text { Management process of planning, organization, motivation and control for material, } \\
\text { technical, financial, personnel provision of artistic and production processes in } \\
\text { theatrical and entertainment organizations. Management of theatre buildings and stage } \\
\text { equipment operation. }\end{array}$ \\
\hline $\begin{array}{l}\text { Performer } \\
\text { management }\end{array}$ & $\begin{array}{l}\text { Organization of performers' work, communication with various concert and tour } \\
\text { organizing companies, administrative work for creating new "celebrities", search for } \\
\text { talented actors and performers, organization of their activity: repertory selection, } \\
\text { investor search, scenic image development, career planning (Prigozhin I.I.) }\end{array}$ \\
\hline $\begin{array}{l}\text { Choreographic } \\
\text { management }\end{array}$ & $\begin{array}{l}\text { A type of management activity ensuring show trial and technological processes of } \\
\text { preparation, promotion and run of a choreographic performance }\end{array}$ \\
\hline Circus management & $\begin{array}{l}\text { Organization of planning and management of a circus program in the process of } \\
\text { artistic, creative, production work and further presentation of the program to the } \\
\text { audience }\end{array}$ \\
\hline $\begin{array}{l}\text { Concert, festival and } \\
\text { tour management }\end{array}$ & $\begin{array}{l}\text { A type of organizational and managerial activities focusing on the production of mass } \\
\text { events, performances, theatre shows and celebrations, concerts, show and programs }\end{array}$ \\
\hline \multicolumn{2}{|r|}{ Visual art management } \\
\hline $\begin{array}{l}\text { Cinema and } \\
\text { television } \\
\text { management }\end{array}$ & $\begin{array}{l}\text { Preparation and run of film, TV series, TV broadcast and TV program making process. } \\
\text { Organization of distribution and broadcast. Assessment of artistic value and audience } \\
\text { potential of cinema, media and TV projects }\end{array}$ \\
\hline $\begin{array}{l}\text { Fine and applied arts } \\
\text { management }\end{array}$ & $\begin{array}{l}\text { Planning and organization of activities in the field of creation, storage and promotion } \\
\text { of paintings, installations, decorations, decorative and applied art objects }\end{array}$ \\
\hline $\begin{array}{l}\text { Museum, gallery } \\
\text { and exhibition } \\
\text { management }\end{array}$ & $\begin{array}{l}\text { Design and run of art projects, art products in the field of museum business and } \\
\text { art industry: auctions, art dealers, experts, collectors, museums, art galleries. } \\
\text { Organization and run of various exhibitions, transition of classic gallery business into } \\
\text { the modern format of performances, happenings, shows and other innovative forms } \\
\text { and formats of art presentation }\end{array}$ \\
\hline
\end{tabular}

and development of culture and art specialists;

- ensuring development and making of sufficient decisions in the field of art development, sociocultural environment creation, artistic education and breeding.

With the help of systematic analysis of modern art management practice, we may outline the following varieties of art management and demonstrate them in Table 1.

As long as one of the major functions of art management is the management of complex cultural, artistic and educational processes, from the philosophic and culturological point of view it is especially relevant to study art management as an open system and the opportunities it encompasses for the management of personal, social and professional development of a specialist working in the field of art and creative practices.

The core of art management manifests itself in the process of functioning. Based on the methodological sociocultural base of art management, its functions are revealed 
Table 2. Art management function

\begin{tabular}{|c|c|}
\hline Art management functions & Explanation \\
\hline Target setting & $\begin{array}{l}\text { Process of forming a target as an ideal image of suggested state of the art field } \\
\text { and its actualization in an objectively real result of an artistic practice }\end{array}$ \\
\hline $\begin{array}{l}\text { Forecast (foresight, } \\
\text { prediction) }\end{array}$ & $\begin{array}{l}\text { Determination of tendencies, prospects and strategies of art development based } \\
\text { on the data of its past, actual functioning and transformation }\end{array}$ \\
\hline $\begin{array}{l}\text { Planning (from Latin planus: } \\
\text { plain, flat) }\end{array}$ & $\begin{array}{l}\text { A process intended to determine objectives, tasks, indicators, criteria, tempos, } \\
\text { terms of implementation of projects and art objects in the spheres of artistic } \\
\text { culture and art, sociocultural systems or their components with regard to } \\
\text { development, purposeful regulation of factors and resources }\end{array}$ \\
\hline Decision making & $\begin{array}{l}\text { Research-based selection of one possible solution for a task or a problem } \\
\text { based on the systematic analysis of the sociocultural situation and adequate } \\
\text { information support }\end{array}$ \\
\hline $\begin{array}{l}\text { Organization (from Late } \\
\text { Latin organizo - make } \\
\text { something neat) }\end{array}$ & $\begin{array}{l}\text { Totality of processes or actions leading to the formation and evolution of } \\
\text { interconnections between different parts of one whole; aggregation of artistic } \\
\text { process subjects' activity and development of an artistic branch }\end{array}$ \\
\hline $\begin{array}{l}\text { Actualization (from Latin } \\
\text { actualis - active, practical) }\end{array}$ & $\begin{array}{l}\text { Implementation, putting a plan, project, program, idea, intention etc. into } \\
\text { artistic practice }\end{array}$ \\
\hline $\begin{array}{l}\text { Coordination (from Latin } \\
\text { co- together and ordinatio - } \\
\text { adjustment) }\end{array}$ & $\begin{array}{l}\text { Establishment and harmonization of functional interdependence between } \\
\text { the activities of culture, art institutions, professional performers, performing } \\
\text { groups and different means for target achievement }\end{array}$ \\
\hline $\begin{array}{l}\text { Regulation (from Latin } \\
\text { regulo- organize, put into } \\
\text { order) }\end{array}$ & $\begin{array}{l}\text { Process of purposeful managerial influence to ensure balance in an artistic } \\
\text { process and its development by introduction of different regulators (rules, } \\
\text { regulations, targets, connections) }\end{array}$ \\
\hline $\begin{array}{l}\text { Motivation (from Latin } \\
\text { moveo - factor) }\end{array}$ & $\begin{array}{l}\text { Realization of the situation by the artistic activity subject, assessment of } \\
\text { different behavior models, expected results and formation of motives on this } \\
\text { base }\end{array}$ \\
\hline $\begin{array}{l}\text { Stimulation (from Latin } \\
\text { stimulus - a goad, a sharp } \\
\text { stick for goading cattle) }\end{array}$ & $\begin{array}{l}\text { Process of encouragement of an artistic activity subject for action, boost of } \\
\text { external activity }\end{array}$ \\
\hline $\begin{array}{l}\text { Control (management, } \\
\text { direction, supervision, } \\
\text { verification, regulation) }\end{array}$ & $\begin{array}{l}\text { Supervision and monitoring for ensuring functioning and development of a } \\
\text { sociocultural system in accordance with the common rules and regulations }\end{array}$ \\
\hline
\end{tabular}

through the fulfillment of features and qualities of a managerial process within the general structure of the society, ensuring the balance, coordination and support for artistic culture development. Such functions are presented in Table 2.

Considering the art management functioning process, E.F. Komandyshko considers it right to outline two groups of functions:

- Main general functions associated with direction and organization of artistic and creative activities (planning, organization, motivation, control);
- Main specific functions associated with art (its purpose and art consumption).

Therefore we can state that modern art management is a system of targets, principles, functionsandtechnologiesinsocioculturalactivity, ensuring the development and implementation of a complex of tactical and strategic actions in accordance with the philosophy and mission of cultural and art institutions.

Generalizing and systematizing the impressions that have developed within the study of art management as an integral part of regulation of the spheres of culture and art, it is important 
to realize that the socioeconomic problems of Russian society cannot but make an impact on the content of artistic culture and education.

For this reason the managerial activity concepts and strategies shall be intended to develop mechanisms of implementation of scientific, practical, cultural, educational programs of preservation, operation and popularization of objects of historical, cultural, artistic heritage, collections of works of art.

\section{References}

1. Alexeeva E.K. Traditsionnaia kul'tura narodov Severa $v$ sovremennom sel'skom prostranstve (na primere evenov Iakutii) [Traditional Culture Of The Northern Nations In The Modern Village Space (Based On Yakut Evens)] // Molodoy uchionyy, 2011. № 7-2. P. 35-37.

2. Anurin V.F. Religiia kak faktor sotsial'noy integratsii [Religion As A Social Integration Factor] // Sotsiologicheskie issledovaniia. 2013. № 01. P. 135-146.

3. Arnol'dov A.I. Kul'turnaia politika: realii $i$ tendentsii [Culture Policy: Realities And Tendencies]. Moscow: MGUKI, 2004. 64 p.

4. Arutiunov S.A. Kul'turnaia antropologiia [Cultural Anthropology]. Moscow: Ves' Mir Publishing House, 2004. 216 p.

5. Akhutin A.V., Vizgin V.P., Voronin A.A. et al. Teoreticheskaia kul'turologiia [Cultural Studies Theory]. Moscow: Akademicheskiy Proekt: Yekaterinburg: Delovaia Kniga, 2005. 624 p.

6. Babenko A.V. O menedzhmente khudozhestvennogo rynka v izobrazitel'nom iskusstve [On Art Market Management In Visual Art] // Tomsk State University Newsletter. 2013. № 366. P. 110-111.

7. Bulatov M.A. Dialektika i kul'tura (istoriko-filosofskiy analiz) [Dialectics And Culture (Historical And Philosophical Review)] Kiev: Naukova dumka, 1984. 216 p.

8. Bourdieu P. Sotsial'noe prostranstvo: polia i praktiki [Social Space: Fields And Practices]. Saint Petersburg: Aleteyia, 2005. 576 p.

9. Bystrova A.N. Problema kul'turnogo prostranstva (opyt filosofskogo analiza) [Cultural Space Problem (Philosophic Analysis Experience)]: monograph. Novosibirsk: Siberian Branch of Russian Academy of Science, 2004. 240 p.

10. Vostriakov L.E. Regional'naia kul'turnaia politika poreformennoy Rossii: sub'ektnoe izmerenie [Regional Cultural Policy of Reformed Russia: Subjective Aspect]. Saint Petersburg: SZAGS Publishing House, 2005. 344 p.

11. Gadzhiev K.S. Natsional'naia identichnost': kontseptual'nyy aspekt [National Identity: Conceptual Aspect] // Voprosy filosofii, 2011. № 10. P. 3-16.

12. Galutskiy G.M. Upravliaemost' kul'tury i upravlenie kul'turnymi protsessami [Manageability Of Culture And Cultural Processes' Management]. Moscow, 1998. 464 p.

13. Grachev V.I. Kommunikativnye kul'turfenomeny i paradoks sovremennogo rossiyskogo art-menedzhmenta [Communicative Culture Phenomena And Paradox Of Modern Russian Art Management] // Newsletter of Moscow State University of Culture and Arts, 2006. № 1. P. 81-86.

14. Dragichevich-Sheshich M. Marketing organizatsiy kul'tury [Cultural Institutions Marketing] / Art Manager / Zhurnal dlia professionalov. Moscow: CJSC Holding Company Blitz Inform, 2002, № 1. P. 27-28. 
15. Yezhova E.Iu. Khudozhestvennaia kul'tura lichnosti v polikul'turnom prostranstve [Artistic Culture Of A Personality In A Polycultural Space] // Lichnost'. Kul'tura. Obshchestvo. 2009. V. XI. № 4. P. 361-363.

16. Yestrina O.V. Rossiyskoe sotsiokul'turnoe prostranstvo i determiniruiushchie ego faktory [Russian Sociocultural Space And Determining Factors] // Volgograd State University Newsletter. Series 7: Philosophy. Sociology and social technologies. 2009. № 1. P. 47-51.

17. Zhdanova E.I., Ivanov S.V., Krotova N.V. Upravlenie i ekonomika vshou-biznese [Management And Economics Of Show Business]. Moscow: Finansy i statistika, 2003. 176 p.

18. Zhidkov V.S. Gosudarstvennaia kul'turnaia politika [Governmental Cultural Policy]// Orientiry kul'turnoy politiki. Moscow: Main Information and Calculation Centre of the Ministry of Culture of the Russian Federation, 2001. № 6. P. 10-15.

19. Zaborova E.N., Islamova A.F. Gorod kak sotsial'noe prostranstvo [City As A Social Space] // Sotsiologicheskie issledovaniia. 2013. № 02. P. 97-100.

20. Zamiatin D.N. Obraz naslediia $v$ kul'ture. Metodologicheskie podkhody $k$ izucheniiu poniatiia naslediia [Heritage In Culture. Methodological Approach To Heritage Concept Studies] // Sotsiologicheskie issledovaniia. 2010. № 02. P. 75-82.

21. Zapesotskiy A.S. Obrazovanie: filosofiia, kul'turologiia, politika [Education: Philosophy, Culture Studies, Politics]. Moscow: Nauka, 2003. 456 p.

22. Zapesotskiy A.S., Markov A.P. Sovremennaia kul'turologiia kak nauchnaia paradigma [Modern Culture Studies As A Scientific Paradigm] // Voprosy filosofii. 2010. № 8. P. 76-87.

23. Zborovsky G.E. Prostranstvo i vremia kak formy sotsial'nogo bytiia [Space And Time As Forms Of Social Being]. Sverdlovsk: Law Institute, 1974, 105 p.

24. Ikonnikova S.N. Arkhitektonika i dinamizm kul'turnogo prostranstva Rossii [Architectonics And Dynamism Of Russian Cultural Space] // Gumanitarnye nauki. 1997. № 2. P. 93-97.

25. Il'enkov E.V. Filosofiia i kul'tura [Philosophy And Culture]. Moscow: Politizdat, 1991. $464 \mathrm{p}$.

26. Kagan M.S. Chelovecheskaia deiatel'nost' (Opyt sistemnogo analiza) [Human Activities (Systematic Analysis Experience)]. Moscow: Politizdat, 1974. 328 p.

27. Kazieva A.M. Natsional'naia kul'tura i eio mesto $v$ tsivilizovannom prostranstve strany [National Culture And Its Place In The Civilized Space Of The Country] // Gumanitarnye issledovaniia. 2012. № 1. P. 7-12.

28. Kasatkina S.A. Menedzhment $v$ sfere kul'tury kak vid upravlencheskoy deiatel'nosti [Management In The Field Of Culture As A Type Of Managerial Activity] // Newsletter of Moscow State University of Culture and Arts. 2011. № 6. P. 200-204.

29. Kasatkina S.A. Sovremennyy sotsiokul'turnyy menedzhment: izmerenie tsennostnykh osnovaniy [Modern Sociocultural Management: Axiological Basis Aspect] // Newsletter of Moscow State University of Culture and Arts. 2013. № 3. P. 204-208.

30. Kirko V.I., Verkhovets S.V., Keush A.V. Rol' federal'nykh universitetov v formirovanii innovatsionnoy regional'noy struktury (na primere Sibirskogo federal'nogo universiteta) [Role Of Federal Universities In Forming Innovative Regional Structure (Based On Siberian Federal University) / Innovatsii. 2010. № 10. P. 60-64. 
31. Kirko V.I., Zakharova K.N. Traditsionnaia khoziaystvennaia deiatel'nost' etnosokhraniaiushchiy obraz zhizni [Traditional Economic Activity: Ethnos-Preserving Lifestyle] // Arktika i Sever. 2013. № 12. P. 24-31.

32. Kistova A.V. Metodologicheskoe znachenie "ponimaiushchey germenevtiki" Vil'gel'ma Dil'teia dlia sotsial'no-filosofskogo issledovaniia sovremennykh sotsiokul'turnykh fenomenov [The Methodological Significance Of "Understanding Hermeneutics" Of Wilhelm Dilthey For SocioPhilosophical Study Of Contemporary Socio-Cultural Phenomena] // Sovremennye problemy nauki i obrazovaniia. 2013. 2013. № 3. P. 450.

33. Kolber F., Evrar I. Art-menedzhment nauka tret'ego tysiacheletiia [Art Management: The Third Millennium Science] // Art Manager / Zhurnal dlia professionalov. M.: CJSC Holding Company Blitz Inform, 2002, № 3. P. 3-7.

34. Kolganova A.A. Prostranstvo dukhovnoy raboty. Iskusstvo pomogat' iskusstvu [Spiritual Work Space. Art To Help Art] // Bibliotechnoe delo. 2012. № 10. P. 2-8.

35. Komandyshko E.F. Razvitie kul'turno-tvorcheskoy initsiativy studentov vuza v usloviiakh osvoeniia art-menedzhmenta [Development Of Cultural And Creative Incentives Of Art Management Studying College Students] // Pedagogika iskusstva. 2009. № 2. P. 88-97.

36. Kononenko B.I. Bol'shoy tolkovyy slovar' po kul'turologii [Big Culture Studies Explanation Dictionary]. Moscow: Veche 2000, 2003. 512 p.

37. Koptseva N.P., Luzan V.S. Gosudarstvennaia kul'turnaia politika v Sibirskom federal'nom okruge: kontseptsii, problemy, issledovaniia [State Cultural Policy Of Siberian Federal District: Concepts, Problems, Research]: monograph. Krasnoyarsk: SFU Publishing House, 2012.

38. Koptseva N.P. Vvedenie valetologiiu [Introduction To Alethology]. Krasnoyarsk: Krasnoyarsk State University, 2002.

39. Koptseva N.P. Istina v filosofii Platona [The Truth In Plato Philosophy] // Filosofiia i kul'tura. 2013. № 4. P. 429-436.

40. Koptseva N.P. Problema istiny v filosofii religii. Spetsifika kontseptualizatsii istiny v buddiyskoy filosofii [The Problem Of Truth In The Philosophy Of Religion. Specificity Of Conceptualization Of Truth In Buddhist Philosophy] // Filosofiia i kul’tura. 2013. № 11. P. 1564-1573.

41. Koptseva N.P. Filosofiia $i$ iskusstvo: edinstvo myslitel'nogo prostranstva [Philosophy And Art: Integrity Of Thinking Space] // Scholarly Notes of the Art Theory and Cultural Studies Department. Issue 1. Krasnoyarsk, 2000.

42. Koptseva N.P. Integratsiia gumanitarnogo obrazovaniia $v$ Sibirskom federal'nom universitete [Integration Of Humanities Education At Siberian Federal University] // Vysshee obrazovanie segodnia. 2007. № 4. P.6-8.

43. Koptseva N.P. Teoriia $i$ praktika innovatsionnoy obrazovatel'noy programmy po esteticheskomu tsiklu distsiplin [Theory And Practice Of An Innovative Educational Program In The Aesthetic Disciplines Cycle] // Vysshee obrazovanie segodnia. 2007. № 12. P. 9-13.

44. Koptseva N.P. Kul'turologicheskaia baza formirovaniia obshcherossiyskoy natsional'noy identichnosti $v$ Sibirskikh regionakh Rossiyskoy Federatsii [Cultural Base For Forming AllRussian National Identity In The Siberian Regions Of The Russian Federation] // Volgograd State University Newsletter. Series 7. Philosophy, Sociology and Social Technologies. 2012. № 3. P. 11-15. 
45. Koptseva N.P. Metodologicheskie vozmozhnosti sotsial'noy (kul'turnoy) antropologii dlia sovremennykh kul'turnykh issledovaniy [Methodological Opportunities Of Social (Cultural) Anthropology For Contemporary Cultural Research] // Filosofiia i kul'tura. 2012. № 10. P. 9-18.

46. Koptseva N.P. Problema metodologii sovremennykh kul'turnykh issledovaniy: vozmozhnosti klassicheskoy britanskoy sotsial'noy antropologii [Methodology Problem Of The Contemporary Cultural Research: Prospects Of Classic British Social Anthropology] // Gumanitarnye i sotsial'nye nauki. 2012. № 4. P. 89-104.

47. Koptseva N.P. Provedenie eksperimental'nogo prikladnogo kul'turnogo issledovaniia mezhkul'turnoy kommunikatsii:fokus-gruppy, lichnoe interv'iu, anketirovanie, poluchenie ekspertnogo mneniia (na materiale issledovaniia Krasnoyarskogo kraia) [Experimental Applied Cultural Research In Intercultural Communication: Focus Groups, Personal Interview, Questionnaires, Expert Opinion (Based On Research Of Krasnoyarsk Region) [Electronic Source] // Sovremennye problemy nauki i obrazovaniia. 2013. № 3.

48. Koptseva N.P., Libakova N.M. Produktivnost' gendernogo podkhoda dlia gumanitarnykh issledovaniy [Productivity Of The Gender Approach For Humanitarian Research] [Electronic Source] // Sovremennye problemy nauki i obrazovaniia. 2013. № 1.

49. Koptseva N.P. i Nevol'ko N.N. Vizualizatsiia etnicheskikh traditsiy $v$ zhivopisnykh $i$ graficheskikh proizvedeniiakh khakasskikh masterov [Visualization Of Ethnical Traditions In Paintings And Graphics By Khakass Artists] // Iskusstvo i obrazovanie. 2012. № 1. P. 27.

50. Korennye malochislennye narody Severa i Sibiri v usloviiakh global'nykh transformatsiy (na materiale Krasnoiarskogo kraia). Chast' 1. Kontseptual'nye i metodologicheskie osnovy issledovaniia. Etnokul'turnaia dinamika korennykh malochislennykh narodov Krasnoiarskogo kraia [Indigenous Small-Numbered Peoples Of The North And Siberia Under The Conditions Of Global Transformations (Based On Krasnoyarsk Region). Part 1. Conceptual And Methodological Bases For The Research. Ethnocultural Dynamics Of Indigenous Small-Numbered Peoples Of Krasnoyarsk Region] / Amosov A.E., Koptseva N.P., Libakova N.M., Reznikova K.V., Sertakova K.V., Pimenova N.N., Kistova A.V. et al. Edited by N.P. Koptseva. Krasnoyarsk: Siberian Federal University Publishing House, 2012. 640 p.

51. Kostylev S.V., Koptseva N.P. Primenenie metodov $i$ tekhnologiy art-menedzhmenta $v$ sotsiokul'turnom obrazovatel'nom prostranstve Krasnoiarskogo kraia [Application Of Art Management Methods And Technologies In The Sociocultural Educational Space Of Krasnoyarsk Region] [Electronic Source] // Sovremennye problemy nauki i obrazovaniia. 2013. № 4.

52. Kotler Ph., Scheff J. Vse bilety prodany. Strategii marketinga ispolnitel'skikh iskusstv [Standing Room Only. Strategies For Marketing The Performing Arts]. Moscow: Klassika XXI, 2004. $688 \mathrm{p}$.

53. Kravtsova E.I. Khudozhestvennoe vremia $i$ prostranstvo $v$ lingvokul'turologicheskom diskurse [Time And Space Of Art In Linguistic And Culturological Discourse] // Mir nauki, kul'tury, obrazovaniia. 2010. № 3. P. 278-281.

54. Kravchenko A.I. Kul'turologiia: Slovar' [Cultural Studies: Dictionary] Moscow: Akademichskiy proekt, 2001. $672 \mathrm{p}$.

55. Kreativnaia laboratoriia: dialog tvorcheskikh praktik [Creative Laboratory: Creative Practices’ Dialogue]: monograph. Edited by O.A. Karlova. Moscow: Akademicheskiy proekt, 2009. $476 \mathrm{p}$. 
56. Kudrina S.A. Tsennostnye prioritety i ikh ontologicheskie osnovaniia [Value Priorities And Their Ontological Bases] // Sotsiologicheskie issledovaniia. 2010. № 02. P. 37-46.

57. Kul'tura i kul'turologiia: Slovar' [Culture And Cultural Studies: Dictionary] compiled and edited by A.I. Kravchenko. Moscow: Akademicheskiy proekt, 2003. 928 p.

58. Kul'tura korennykh i malochislennykh narodov Severa v usloviiakh global'nykh transformatsiy [Culture Of Indigenous And Small-Numbered Peoples Of The North Under The Conditions Of Global Transformations]: monograph / N.P. Koptseva, E.A. Sertakova, M.I. Il'beykina, Iu.S. Zamaraeva, N.M. Libakova, V.S. Luzan et al. // edited by N.P. Koptseva. Saint Petersburg: Eydos, 2011. 174 p.

59. Kul'turnaia politika v Rossii: istoriia i sovremennost' [Culture Policy In Russia: History And Modernity] / edited by I.A. Butenko, K.E. Razlogov. Moscow: Liberia, 1998. P. 193.

60. Kul'turologiia. XX vek. Entsiklopediia [Cultural Studies. 20 ${ }^{\text {th }}$ Century. Encyclopaedia] Volume 2. Saint Petersburg: Universitetskaia kniga. 1998. 447 p.

61. Lavrenova O.A. Kul'tura i prostranstvo: noosfera, pnevmatosfera i semiosfera kak bazisnye kontsepty [Culture And Space: Noosphere, Pneumatosphere, And Semiosphere As Basic Concepts] // Novosibirsk State University Newsletter. Series: Philosophy. 2010. Vol.8. № 1. P. 90-95.

62. Levi-Strauss C. Strukturnaia antropologiia [Structural Anthropology]. Moscow: Glavnaia redaktsiia vostochnoy literatury, $1985.536 \mathrm{p}$.

63. Libakova N.M. Modifikatsii gendernykh obrazov v rossiykoy kul'ture kontsa XIX nachala XXI $v v$. [Gender Image Modifications In Russian Culture Of Late $19^{\text {th }}$ Early $21^{\text {st }}$ Centuries]: dissertation for the academic degree of a Candidate of Philosophic Science: 24.00.01 / Libakoba Natal'ia Mikhaylovna; [Place of presentation: Yaroslav-the-Wise Novgorod State University]. Krasnoyarsk, 2011. 155 p.

64. Luzan V.S. Konteksty ponimaniia intellektual'nogo dosuga v sovremennykh rossiyskikh issledovaniiakh [Contexts Of Intellectual Leisure Understanding In Contemporary Russian Research] // V.P. Astafyev Krasnoyarsk State Pedagogical University Newsletter. 2013. № 4(26). P. 175-178.

65. Luzan V.S. Sotsial'no-filosofskiy analiz dinamiki gosudarstvennoy kul'turnoy politiki Rossiyskoy Federatsii [Social And Philosophic Analysis Of State Culture Policy Dynamics In The Russian Federation]: dissertation for the academic degree of a Candidate of Philosophic Science: 09.00.11 / Luzan Vladimir Sergeevich [Place of presentation: Siberian Federal University]. Krasnoyarsk, 2011. $170 \mathrm{p}$.

66. Losev A.F. Filosofia. Mifologiia. Kul'tura [Philosophy. Mythology. Culture] Moscow: Politizdat, 1991. $525 \mathrm{p}$.

67. Lotman Iu.M. Semiosfera [Semiosphere]. Saint Petersburg: Iskusstvo, 2000. 704 p.

68. Malianov E.A. Sotsial'no-kul'turnye innovatsii $v$ kul'turnom prostranstve regiona [Sociocultural Innovations In The Cultural Space Of The Region]: monograph. Perm: Perm State Institute Of Arts and Culture, 2010. 342 p.

69. Markov B.V. Liudi i znaki: antropologiia mezhlichnostnoy kommunikatsii [People And Signs; Anthropology Of Interpersonal Communication]. Saint Petersburg: Nauka, 2011. 667 p.

70. Makhlina S.T. Semiotika kul'tury povsednevnosti [Semiotics Of The Everyday Life Culture]: monograph. Saint Petersburg: Aleteyia, 2009. 232 p.

71. Mezhuev V.M. Ideia kul'tury. Ocherki po filosofii kul'tury [Idea Of Culture. Essays On The Philosophy Of Culture]. Moscow: Progress-Traditsiia, 2006. 408 p. 
72. Mel'nikova L.V. Problema kul'turnoy identichnosti: kontseptual'nye podkhody [Cultural Identity Problem: Conceptual Approaches] // Gumanitarnye i sotsial'nye nauki. 2010. № 5. P. 226234.

73. Mirzoian V.A. Upravlenie kak predmet filosofskogo analiza [Management As An Object Of Philosophical Analysis] // Voprosy filosofii. 2010. № 4. P. 35-47.

74. Molchanov V.I. Istoriia i prostranstvo. Destruktsiia temporal'noy istorichnosti [History And Space. Temporal Historicity Destruction] // Voprosy filosofii. 2013. № 7. P. 24-36.

75. Mol' A. Sotsiodinamika kul'tury [Sociodynamics Of Culture] Moscow: Progress, 1973. $406 \mathrm{p}$.

76. Moskaliuk M.V. Vsio, chto v serdtse. Khudozhniki Krasnoiar'ia vchera, segodnia, zavtra [All That Is In My Heart. Artist Of Krasnoyarsk Yesterday, Today, Tomorrow] Krasnoyarsk: Polikor, 2010. $288 \mathrm{p}$.

77. MochalovD.V.Menedzhmentkul'turyiart-menedzhment:vzaimosviaz'ivzaimoobuslovlennost' [Culture Management And Art Management: Interconnection And Interdependence] // Newsletter of Kazan State University of Culture and Arts. 2011. № 4. P. 47-51.

78. Nazarchuk A.V. Sotsial'noe vremia $i$ sotsial'noe prostranstvo v kontseptsii setevogo obshchestva [Social Time And Social Space In The Network Society Concept] // Voprosy filosofii. 2012. № 9. P. 56-66.

79. Naumova E.G. Tvorchestvo i tvorcheskaia lichnost'v sovremennoy reprezentativnoy kul'ture [Creativity And Creative Personality In Contemporary Representative Culture] // Gumanitarnye i sotsial'nye nauki. 2012. № 2. P. 356-365.

80. Nemirovskiy V.G. Massovoe soznanie zhiteley Sibirskogo regiona: predstavleniia o sebe i o Rossii [Mass Consciousness Of The Siberian Region Citizens: Self-Perception And Ideas Of Russia] // Sotsiologicheskie issledovaniia. 2013. № 04. P. 54-59.

81. Novoe budushchee Sibiri: ozhidaniia, vyzovy, resheniia [New Future Of Siberia: Expectations, Challenges, Solutions]: monograph / N.A. Bakhova, A.V. Bukharov, E.A. Viktoruk, M.I. Il'beykina et al. // edited by O.A. Karlova, N.P. Koptseva. Electronic source. Krasnoyarsk: Siberian Federal University, 2013.

82. Novatorov V.E. Innovatsionnyy menedzhment $v$ sfere kul'tury [Innovative Management In The Field Of Culture]: monoanthology. Omsk, OSU, 2007. 358 p.

83. Novaia filosofskaia entsiklopediia [New Encyclopaedia Of Philosophy]: in 4 volumes. Institute of Philosophy of Russian Academy of Science. Moscow: Mysl', V. 3. 2010. 692 p.

84. Novikova G.N. Sotsiokul'turnye kontseptsii upravleniia $v$ art-menedzhmente [Sociocultural Concepts Of Administration In Art Management] // Newsletter of Moscow State University Of Culture And Arts. 2005. № 2. P. 83-88.

85. Petrova O.F. Novoe v sovremennykh issledovaniiakh po voprosam art-menedzhmenta i artmarketinga [New In Contemporary Research Of Art Management And Art Marketing] // Humanitarian culture as a factor of transformation of Russia. Science Day at Saint Petersburg Humanitarian University of Trade Unions: proceedings of International Scientific and Practical Conference, May 21-22 1998. / edited by V.E. Triodin. Saint Petersburg: SPHUTU, 1998. P. 258-259.

86. Pichko N.S. Dukhovno-nravstvennye aspekty lichnosti v kontekste kul'tury: teoreticheskoe osmyslenie problemy [Spiritual And Moral Aspects Of Personality In The Context Of Culture: 
Theoretical Understanding Of The Problem] // Gumanitarnye i sotsial'nye nauki. 2011. № 4. P. 267-275.

87. Podbolotov P.A. Universitet kul'tury i iskusstv kak model' kul'turnogo prostranstva Rossii [University Of Culture And Arts As A Model Of Cultural Space Of Russia] // Kul'tura: upravlenie, ekonomika, pravo. 2009. № 2. P. 18-21.

88. Pozdniakova O.A., Reznikova K.V. Osobennosti sub'ektov khudozhestvennoy kinokommunikatsii [Specificity Of Subjects Of Artistic Cinema Communication] [Electronic source] // Sovremennye problemy nauki i obrazovaniia. 2013. № 4.

89. Reznikova K.V. Znachenie kinematografa dlia formirovaniia obshcherossiyskoy natsional'noy identichnosti [Significance Of Cinematograph For Formation Of All-Russian National Identity] [Electronic Source] // Sovremennye problemy nauki i obrazovaniia. 2013. № 3.

90. Reznikova K.V. Sotsial'noe konstruirovanie obshchenatsional'noy identichnosti v Rossiyskoy Federatsii [Social Construction Of All-Russian National Identity In The Russian Federation]: Abstract from the dissertation for the academic degree of a Candidate of Philosophic Science: 09.00.11/ Reznikova Kseniia Viacheslavovna; [Place of presentation: Siberian Federal University]. Krasnoyarsk, 2012. $20 \mathrm{p}$.

91. Popkov Iu.V., Tiugashev E.A. Filosofiia Severa: korennye malochislennye narody Severa $v$ stsenariiakh miroustroystva [Philosophy Of The North: Indigenous Small-Numbered Peoples Of The North In The World Order Scenarios]. Salekhard. Novosibirsk: Sibirskoe nauchnoe izdatel'stvo, 2006. 376 p.

92. Reichenbach H. Filosofiia prostranstva i vremeni [The Philosophy Of Space And Time] Moscow: Progress, 1985. 344 p.

93. Savel'eva E.A. Prostranstvo khudozhestvennogo muzeia kak sredstvo realizatsii pedagogicheskogo vzaimodeystviia [Art Museum Space As A Means For Pedagogical Interaction] // Srednee professional'noe obrazovanie. 2010. № 1. P. 46-48.

94. Sanina A.G. Gosudarstvennaia identichnost': izderzhki virtualizatsii [State Identity: Costs Of Virtualization] // Sotsiologicheskie issledovaniia. 2012. № 03. P.77-87.

95. Semionova A.A. Vizual'naia kul'tura modernizirovannogo sotsiuma [Visual Culture Of The Modernized Society] // Volgograd State University Newsletter. Series 7. Philosophy, sociology and social technologies. 2012. № 3. P. 141-149.

96. Semionova A.A., Gerasimova A.A. Osobennosti tvorcheskogo metoda Sergeiia Anufrieva [Specificity Of Sergei Anufriev Creative Method] [Electric source] // Sovremennye problemy nauki i obrazovaniia. 2013. № 2. P.542.

97. Semionova A.A. Modifikatsii drevnerusskogo kontsepta "gosudarstvo"v rossiyskoy kul'ture XXI veka: metodologicheskiy aspekt [Modifications Of The Old Russian Concept Of "The State" In Russian Culture Of The 21 ${ }^{\text {st }}$ Century: Methodological Aspect]: dissertation for the academic degree of the Candidate of Philosophic Science: 24.00.01 / Semionova Aleksandra Aleksandrovna; [Place of presentation: Yaroslav-the-Wise Novgorod State University]. Krasnoyarsk, 2009. 198 p.

98. Sertakova E.A. Issledovanie "goroda" v klassicheskikh kontseptsiiakh zarubezhnykh uchionykh [Research Of The "City" In Classic Concepts Of Foreign Scholars] [Electronic Source] // Sovremennye problemy nauki i obrazovaniia. 2013. № 4. P. 381. 
99. Sertakova E.A. Kul'turnaia geografiia A. Lefevra $v$ svete gumanitarnykh issledovaniy sotsial'nogo prostranstva goroda [Cultural Geography Of Henri Lefebvre In The Context Of Humanitarian Research Of The Social Space Of The City] // Teoriia i praktika obshchestvennogo razvitiia. 2012. № 3. P.24-26.

100. Sertakova E.A. Funktsionirovanie proizvedeniy iskusstva v seti Internet [Internet Functioning Of Works Of Art] // Nauka i sovremennost’. 2010. № 3-1. P. 64-68.

101. Sizemskaia I.N. Sotsiokul'turnoe prostranstvo Rossii: realii i perspektivy [Sociocultural Space Of Russia: Realities And Prospects] // Obshchestvennye nauki i sovremennost'. 2011. № 4. P. $20-28$.

102. Sil'vestrov V.V. Kul'tura. Deiatel'nost'. Obshchenie [Culture. Activity. Communication]. Moscow: Rossiyskaia politicheskaia entsiklopediia (ROSSPEN), 1998. 478 p.

103. Spirova E.M. Simvol kak poniatie filosofskoy antropologii [Symbol As A Concept Of Philosophical Anthropology] // Voprosy filosofii. 2012. № 3. P. 91-100.

104. Suminova T.N. Formirovanie art-menedzhera kak konkurentosposobnoy i effektivnoy lichnosti velenie vremeni i zadacha vuzov kul'tury $i$ iskusstv [Formation Of An Art Manager As A Competitive And An Efficient Personality: The Dictate Of The Present Time And The Task Of Culture And Arts Colleges] // Moscow State University of Culture and Arts Newsletter. 2013. № 2. P. 175-180.

105. Surtaev V.Ia. Sotsiokul'turnoe prostranstvo molodiozhi: metodologiia, teoriia, praktika [Sociocultural Space Of The Youth: Methodology, Theory, Practice]. Saint Petersburg: Saint Petersburg State University of Culture and Arts, 2006. 272 p.

106. Tonkonogov A.V. Massovaia kul'tura kak faktor formirovaniia dukhovnogo prostranstva sovremennoy Rossii [Mass Culture As A Factor Of Forming The Spiritual Space Of Modern Russia] // Sotsial'no-gumanitarnye znaniia. 2010. № 5. P. 27-37.

107. Fedotova V.G. Edinstvo i mnogoobrazie kul'tur v usloviiakh globalizatsii [Integrity And Diversity Of Cultures Under The Conditions Of Globalization]// Voprosy filosofii. 2011. № 9. P.45-53.

108. Flier A.Ia. Perspektivy kul'turologii v issledovaniiakh sotsial'nykh funktsiy kul'tury [Cultural Studies Prospects In The Research Of Social Functions Of Culture] // Voprosy kul'turologii. 2009. № 5. P. 45-47.

109. Tsybikov T.G. Knizhnaia kul'tura Buriatii v sovremennom informatsionnom prostranstve [Book Culture Of Buryatia In The Modern Information Space] // Bibliografiia: journal on book science and bibliology. 2012. № 1. P. 31-37.

110. Shantsev V.P. Ustoychivoe regional'noe razvitie: sinergeticheskiy splav ekonomiki $i$ upravleniia, chelovecheskikh resursov i traditsii [Sustainable Regional Development: Synergetic Alloy Of Economy And Administration, Human Resources And Traditions] // Voprosy filosofii. 2013. № 1. P. 17-23.

111. Shapinskaia E.N. Kul'tura povsednevnosti kak prostranstvo tolerantnosti [Culture Of Everyday Life As A Space Of Tolerance] // Kul’turologiia. 201. № 3. P. 206-207.

112. Shub M.L. Khudozhestvennoe prostranstvo skvoz' prizmu sovremennykh filosofskokul'turologicheskikh kontseptsiy [Artistic Space Through The Prism Of Contemporary Concepts Of Philosophy And Cultural Studies' // Newsletter of Chelyabinsk State Academy of Culture and Arts. 2007. V.12. № 2. P. 87-93. 


\section{Арт-менеджмент как управленческая система трансляции художественных ценностей}

\section{С.В. Костылев}

Сибирский федеральный университет Россия, 660041, Красноярск, пр. Свободный, 79

В статье рассматриваются особенности функиионирования и развития арт-менеджмента как важнейшего механизма, регулирующего и обеспечивающего систему управления в сфере культуры, искусства и образования, направленную на решение задач сохранения $и$ развития художественного творчества; приумножения эстетических, образовательных, культурно-просветительских, духовно-нравственных и патриотических ценностей; создания, презентачии и продвижения высокохудожественной продукиии искусства. Исследуются разновидности и функиии арт-менеджмента, отвечающие за разработку и реализачию стратегии образовательной деятельности; осуществление систематической деятельности по подготовке, переподготовке $u$ повышению квалификации, общего культурного $u$ профессионального уровня сотрудников учреждений культуры и искусства.

Ключевые слова: арт-менеджмент, разновидности и функции арт-менеджмента, артмаркетинг.

Научная специальность: 24.00.00 - культурология, 09.00.00 - философские науки. 